\title{
The Difference in Physical Fitness Levels of Indonesian Male and Female Junior High School Students
}

\author{
Aprida Agung Priambadha \\ Faculty of Teacher Trainingand Education \\ Ahmad Dahlan University \\ Yogyakarta, Indonesia \\ aprida.priambadha@pgsd.uad.ac.id \\ Dapan \\ Faculty of Sport Science \\ Yogyakarta State University \\ Yogyakarta, Indonesia \\ dapan@uny.ac.id
}

\author{
Fitria Dwi Andriyani \\ Faculty of Sport Science \\ Yogyakarta State University \\ Yogyakarta, Indonesia \\ fitria.dwi.andriyani@uny.ac.id \\ Desi Ardiyani \\ Alumni of Faculty of Sport Science \\ Yogyakarta State University \\ Yogyakarta, Indonesia \\ ardiyanidesi@gmail.com
}

\begin{abstract}
- the limited number of studies which investigates the differences in physical fitness levels between male and female students in Indonesia forms the background of this study. The objective of this study is to investigate the difference in physical fitness levels of male and female students in SMPN 3 Depok Yogyakarta, in the academic year 2015/2016. This research is a comparative descriptive project with a cross-sectional design and the subjects are Grade VIII students (117 students: 54 male, 63 female) aged 13-15 years. The instrument employed in this research is the Indonesian Physical Fitness Test for the 13-15 age-group (Male, validity $=0.950$, reliability $=0.960$; Female, validity $=0.923$, reliability $=\mathbf{0 . 8 0 4})$. The data was analyzed by using a descriptive quantitative analysis and the Mann Whitney $U$ Test. The result of the research show that the overall physical fitness level of the male students is higher than that of the female (the mean of the male students $=14.02 \pm 5.264$, and the mean of the female students $=13.41 \pm 6.601)$. However, there is no significant difference between the physical fitness levels of male and female participants $(\mathrm{sig}=\mathbf{0 . 1 4 4})$. In addition, there is no student who attained a very good physical fitness level and as many as $\mathbf{4 5 . 3 \%}$ students still have a low and a very low physical fitness level. Considering the result above, it is quite evident that physical education needs to be introduced and promoted in schools as the importance of physical activities in improving the physical fitness level of students cannot be overemphasized.
\end{abstract}

Keywords—physical fitness, male, female, students

\section{INTRODUCTION}

Physical activity is an important and inseparable part of human life. Most human actions involve different forms of physical activity. For example, moving from one place to another is done by walking, cycling, or running. Even riding a motorcycle or a car requires a series of coordinated physical movements. Various household activities, such as cleaning a house, washing a car, walking stairs, and watering plants are forms of physical activity.

Experts offer various definitions of physical activity. Caspersen et al. (1984) explained that physical activity is characterized as every motion by skeletal muscles that produces measurable energy expenditure in kilocalories, and can be categorized as activities related to work, exercise, physical conditioning, household and other activities [1]. In the 2008 Physical Activity Guidelines for Americans, it is stated that physical activity is any body movement resulting from the contraction of skeletal muscles that increases the energy expenditure above the basal level, and refers to activities that improve health [2]. Andriyani (2017) also concludes that physical activity is every motion produced by skeletal muscles that results in a greater energy expenditure than what occurs under normal conditions and burns calories. This includes activities related to work, sports, physical conditioning, or household activityies [3].

Physical activity which is done regularly in sufficient quantities will develop physical fitness. Corbin and Lindsey defined physical fitness as the ability of the body system to work efficiently which supports health and abilities to perform everyday life activities effectively [4]. Furthermore Angel (2014) states that physical fitness is a person's ability to perform daily activities without physical exhaustion and injury, and the ability to maintain high levels of energy to complete daily tasks [5].Conclusively Sukarmin and Sudardiyono (2017) mention that physical fitness involves a person's physical ability in terms of physiological change in the body due to certain types of work, and describes a person's degree of health for performing various physical activities, from moderate to high intensity[6]. Thus, a person who has a good level of physical fitness tends to have a good health status and can perform daily activities effectively without a significant fatigue.

Kravitz (2001: 20-21) suggests that for achieving physical fitness, exercise needs to be carried out by considering S.P.O.R.T principle: Specificity, Progression, Overload, Reversibility, and Training Effects. These can be explained as follows:

First and foremost, specificity involves adjusting types of exercise with the goals. The body will adjust to the specificity of the selected exercise. For instance, to develop a cardiorespiratory fitness, then a person may choose a long-distance running exercise, to build muscle strength also, then a person 
can decide to carry out weight training. Secondly, progression means that the intensity of the exercise needs to be adjusted gradually, so that the body can get accustomed to its new abilities and then be able to continue to extend further with the program (injuries can occur because of too much exercise, too fast, and too hard). Thirdly, overload means to set the exercise by adjusting its intensity, duration and frequency a little bit higher than an actual person's capabilities. It can be done by carrying out a long aerobic exercise more often each week, or with higher intensity. Fourthly, reversibility means that people may lose their physical fitness if they do not maintain to do exercise regularly. By stopping practicing, then the skills, endurance, strength and other fitness indicators will decline. Therefore, it is essential to keep doing exercise.

Lastly, training effect refers to the gradual and progressive improvement of the body's physical abilities through exercise. The improvement of muscle and cardio-respiratory conditions are examples of the training effect[7].

In addition, Kravitz explains that individuals also need to pay attention to the formula for aerobic fitness which is F.I.T; Frequency, Intensity, and Time. Frequency here refers to the number of exercise per week. It is suggested that to achieve optimal results it is necessary to undertake aerobic activities 35 times per week. If more practice is desired, it is best to try to take rest at least one day each week to prevent injury due to excessive exercise. In terms of intensity, exercise should be undertaken between $70 \%$ and $85 \%$ of the minimum heart rate, which is known as the training zone. In relation to time, the duration or of an exercise should be gradually increased from 20 to 60 minutes [7].

The application of the above principle and formula to achieve physical fitness is challenging. Changes in the modern lifestyle as well as development of technology has transformed the pattern of human behaviour from being active to inactivity. Various modern conveniences have changed the types of daily activities that people carry out. For example, the existence of modern transportations, such as motorcycle and car, has made people to start walking and cycling less. Furthermore, the availability of gadgets and computer games for children has caused a big increase in their physical inactivity.There is a concurrent gradual decrease in the level of physical activity and physical fitness alongside a shift in behaviors. Studies have reported a high proportion of Indonesian children with low levels of physical activity and/or physical fitness [3, 8, 9, $10,11]$. However, studies that investigate differences in physical fitness levels between male and female students in Indonesia are still limited. As a result of this, this paper intends to investigate the differences in physical fitness levels between male and female junior high school students.

\section{METHODS}

This research is a comparative descriptive research with the aim of investigating the difference in physical fitness levels between the male and female students of SMP N 3 Depok Yogyakarta. This study employed a cross-sectional design.

\section{A. Participants}

The subject of this research are Grade VIII students of SMP N 3 Depok. A total of 117 students $($ male $=54$, female= 63 ) aged 13-15 years were involved in this study.

\section{B. Instrument}

The instrument used in this research is the Indonesian Physical Fitness Test for the 13-15 age-group (male, $v=0.950$, $\mathrm{r}=0.960$; female, $\mathrm{v}=0.923, \mathrm{r}=0.804)$, consisting of 5 items: (1) 50 meters quick run test, (2) arm hang test for female students and 60 second pull up for male students, (3) 60 second sit up test, (4) vertical jump test, and (5) 800 meters run test for female students and 1000 meters for male students[16]

\section{Data Collection and Analysis}

The data analysis technique used is quantitative descriptive analysis and the Mann Whitney U Test with Microsoft Excel and SPSS 23 software.

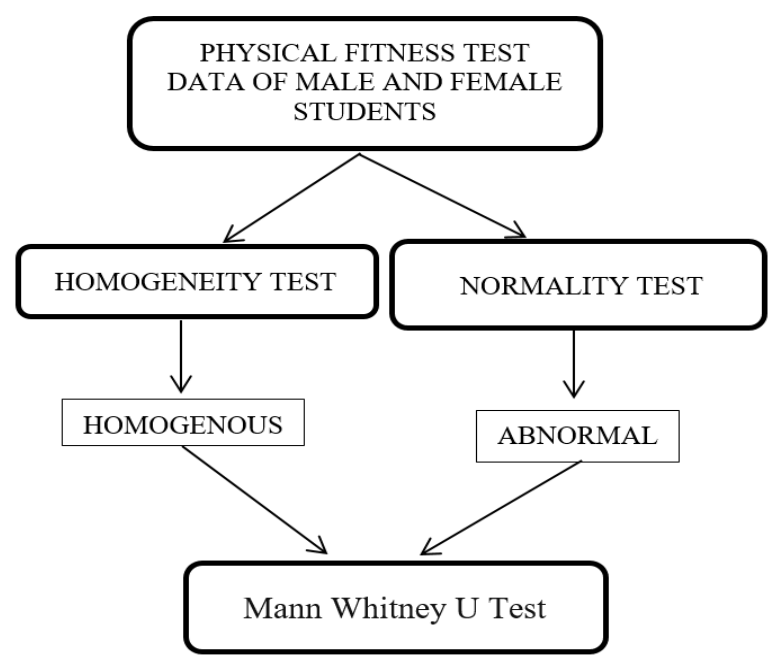

Fig 1. Flow data analysis chart

\section{RESULTS}

The result of the Indonesian Physical Fitness Test showed that there weas no male or female students who had very good physical fitness levels $(0 \%)$. A total of $3.7 \%$ of male students had a good level of physical fitness, whereas the total for female students was $4.8 \%$. More than $\mathrm{h}$ alf of the male participants were at a moderate level of physical fitness $(57.4 \%)$, whereas the rate was $44.4 \%$ for female students. The percentage of male students with a low physical fitness level was $35.2 \%$, while the percentage for female students was $46 \%$. In terms of very low physical fitness levels, 3.7\% male students and $4.8 \%$ female were in this category. The results can be seen in Table 1 below, while the picture can be seen in Figure 2. 
TABLE I. LEVEL OF PhySICAL FITNESS

BASED ON SEX

\begin{tabular}{|c|c|c|c|c|c|c|}
\hline \multirow{3}{*}{$\begin{array}{c}\text { PHYSICAL } \\
\text { FITNESS } \\
\text { LEVEL }\end{array}$} & \multicolumn{4}{|c|}{ SEX } & \multirow{3}{*}{$\begin{array}{l}\text { Total } \\
\text { Frequ } \\
\text { ency }\end{array}$} & \multirow{3}{*}{$\begin{array}{l}\text { Total } \\
\text { Perce } \\
\text { ntage }\end{array}$} \\
\hline & \multicolumn{2}{|c|}{ MALE } & \multicolumn{2}{|c|}{ FEMALE } & & \\
\hline & $\begin{array}{l}\text { Frequ } \\
\text { ency }\end{array}$ & $\begin{array}{l}\text { Perce } \\
\text { ntage }\end{array}$ & $\begin{array}{c}\text { Freq } \\
\text { uency }\end{array}$ & $\begin{array}{l}\text { Perce } \\
\text { ntage }\end{array}$ & & \\
\hline $\begin{array}{l}\text { VERY } \\
\text { GOOD }\end{array}$ & 0 & 0 & 0 & 0 & 0 & 0 \\
\hline GOOD & 2 & 3.7 & 3 & 4.8 & 5 & 4.3 \\
\hline MODERATE & 31 & 57,4 & 28 & 44.4 & 59 & 50.4 \\
\hline LOW & 19 & 35.2 & 29 & 46 & 48 & 41 \\
\hline VERY LOW & 2 & 3.7 & 3 & 4.8 & 5 & 4.3 \\
\hline Total & 54 & 100 & 63 & 100 & 117 & 100 \\
\hline
\end{tabular}

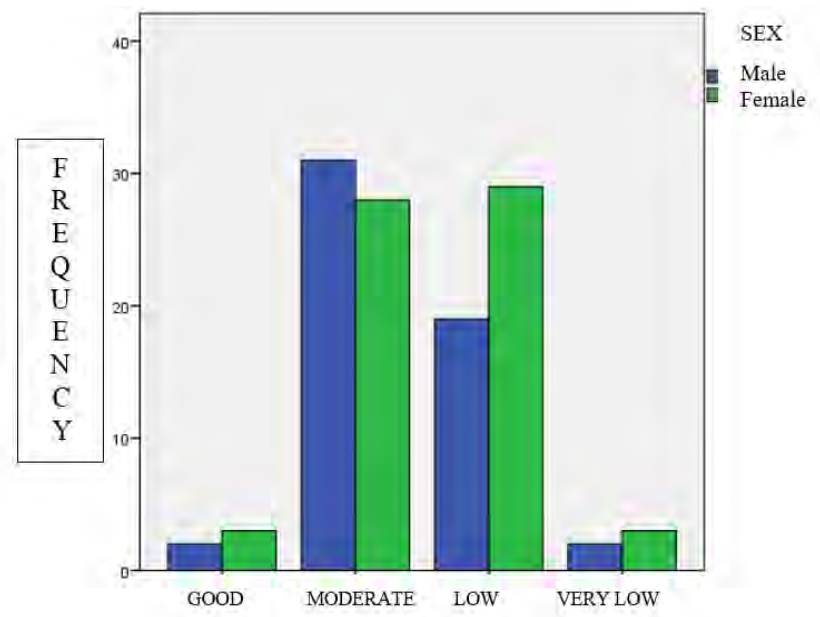

Fig 2. Male and Female Students' Physical Fitness Level

The average physical fitness score of the male students was 14.02 , falling into the moderate category, whereas the score for the female students was 13.41 , which is in the low category. The highest score was achieved on the $50 \mathrm{~m}$ run test and the situp test, either by the male or female students. The lowest score was in long-distance running both on male and female students. Details of the scores are presented in Tables 2 and 3.

TABLE II. Physical Fitness VALUE

\begin{tabular}{|c|r|r|r|r|r|r|}
\hline SEX & Mean & N & \multicolumn{1}{|c|}{$\begin{array}{c}\text { Std. } \\
\text { Deviation }\end{array}$} & Min & Max & Range \\
\hline MALE & 14.02 & 54 & 2.294 & 8 & 19 & 11 \\
FEMA & 13.41 & 63 & 2.569 & 9 & 21 & 12 \\
LE & 13.69 & 117 & 2.455 & 8 & 21 & 13 \\
Total & 13 & & \\
\hline
\end{tabular}

TABLE III. Physical Fitness Test Item VAlue

\begin{tabular}{|c|c|c|}
\hline $\begin{array}{c}\text { PHYSICAL FITNESS } \\
\text { TEST ITEM }\end{array}$ & MALE & FEMALE \\
\cline { 2 - 3 } & MEAN & MEAN \\
\hline 50 M RUN & 4,11 & 3,33 \\
\hline $\begin{array}{c}\text { PULL UP (male)/ARM } \\
\text { HANG (female) }\end{array}$ & 2,35 & 2,38 \\
\hline SIT UP & 3,54 & 3,33 \\
\hline VERTICAL JUMP & 2,78 & 2,75 \\
\hline $\begin{array}{c}800 \mathrm{~m} \\
\text { RUN(female)/1000 m } \\
\text { RUN (male) }\end{array}$ & 1,24 & 1,62 \\
\hline Total & 14,02 & 13,41 \\
\hline
\end{tabular}

Before discrimination testing, the normality and homogeneity test were done (see Table 4 and Table 5). The normality test shows that the data was not normally distributed (significance of $0.009<0.05$ ). The homogeneity test result indicated that the data are homogeneous (significance $0.163>$ 0.05). Based on these results, nonparametric analysis was used, with the Mann Whitney U Test being used to analyze the differences in the physical fitness levels of the male and female students[17].

TABLE IV. NoRmality TEST RESUlt

\begin{tabular}{|c|r|r|r|r|r|r|}
\hline & \multicolumn{3}{|c|}{ Kolmogorov-Smirnov } & \multicolumn{4}{c|}{ Shapiro-Wilk } \\
\cline { 2 - 7 } & Statistic & df & Sig. & Statistic & df & Sig. \\
\hline $\begin{array}{c}\text { Physical } \\
\text { Fitness } \\
\text { Value }\end{array}$ & .097 & 117 & .009 & .980 & 117 & .083 \\
\hline
\end{tabular}

TABLE V. HOMOGENEITY TEST

\begin{tabular}{|c|c|c|c|}
\hline Levene Statistic & df1 & df2 & Sig. \\
\hline 1.968 & 1 & 115 & .163 \\
\hline
\end{tabular}

The Mann Whitney $U$ Test shows the value of $U$ to be 1435.5 , and the value of $W$ to be 3451.5 if converted to a value of Z.Hence the magnitude was -1.462 . The value of Sig or P was $0.144>0.05$. The $p$ value $>$ critical limit was 0.05 , thus there was no significant difference between the two groups. In conclusion, there is no significant difference between the physical fitness levels of the male and female students, as can be seen in Table 6 below.

TABLE VI. MANN Whitney U TEST

\begin{tabular}{|l|c|}
\hline & PHYSICAL FITNESS VALUE \\
\hline Mann-Whitney U & 1435.500 \\
\hline Wilcoxon W & 3451.500 \\
\hline Z & -1.462 \\
\hline Asymp. Sig. (2-tailed) & .144 \\
\hline
\end{tabular}




\section{DISCUSSION}

Although more than half of the male students have a moderate level of physical fitness $(57.4 \%)$, the results of this research reveal the high proportion $(38.9 \%)$ of boys who had a low and a very low physical fitness. For the girls, the results even show a worse condition where a majority among them have a low and very low physical fitness $(50.8 \%)$. The high percentage of students with low and very low physical fitness levels is in line with the findings of research studies on the activities and physical fitness of Indonesian children at various age levels $[3,8,9,10,11]$.

In respect to the group, we can see the male students had a higher physical fitness than the female students (14.02 vs. 13.41), indicating that the male students had better overall physical fitness levels than their female counterparts. One of the causes for this could be the female students' inactivity during physical activities in the physical education class. This result is in line with Vanhelst et al. [13 and Telford et al. [14] who found that boys are fitter and more active than girls. Nevertheless, the lowest physical fitness score is on male students.

Furthermore, from the 5 items of the physical fitness tests, students achieved the lowest values in; the long-distance run, the pull-up/arm hang test, and the vertical jump test. The low scores of both male and female students in these tests indicate the need for teachers and relevant stakeholders to improve the exercise program to increase cardiovascular endurance, strength and the endurance of arm and shoulder muscles, as well as general individual power.

In addition, the result of the analysis shows that although there was a mean difference in physical fitness scores between male and female students, the distinction is not significant (sig $0.144>0.05$ ). Lyyra et al. (2017) found a linear result in their study, which investigated in-class physical activity levels during Physical Education lessons in Finland, showing no significant gender effect $(\mathrm{P}=0.81)$ on students' mean heart rate (MHR) during physical education (PE) lessons [15]. They also stated that the proportion of students engaging in moderate to vigorous Physical Activity (MVPA) during a PE lesson was not affected by gender $(\mathrm{P}=0.88)$ but by lesson content[15]. It is found that boys have a significantly higher MHR than girls while engaged in physical activity,and that boys spent significantly more time in MVPA during PE lessons than girls. But the study also found that girls were more active than boys during games content, while boys were more active during nongames content[15]. The results of this study show that both male and female students need special interventionism physical activity to improve their physical fitness.

\section{CONCLUSIONS}

The conclusion of this research is that there is no significant difference in the physical fitness between male and female students. The fitness component item of the research subjects that needs to be improved based on the Indonesian Physical Fitness Test results are cardiovascular endurance, strength and endurance of arm and shoulder muscles, and general individual power. These results indicate the need for evaluating the implementation of physical education in schools and the importance of physical activity promotion and intervention to improve the physical fitness of students.

\section{ACKNOWLEDGMENT}

We would like to say a big thank you to the school principals and affiliated institutions who permitted us to conduct this study. We will also like to thank all the teachers and students who participated in the study.

\section{REFERENCES}

[1] C. J. Caspersen, K. E. Powell, \& G. M. Christenson, Physical activity, exercise, and physical fitness: definitions and distinctions for healthrelated research,Public Health Reports, 1984;100(2):126-31.

[2] U.S. Department of Health \& Human Services, "2008 Physical activity guidelines for Americans”, 2008, www.health.gov/paguidelines. Accessed on 4 September 2015.

[3] F. D. Andriyani, Status kebugaranjasmanisiswaputrikelas VIII SMP N 3 Depok Yogyakarta,Motion, 2017; VIII(1): 59-66.

[4] C. B. Corbin, \& R. Lindsey, "Fitness for Life Updated Fifth Edition ", 2007, USA: Human Kinetics.

[5] J. Angel, "Find Time to Increase Your Physical Fitness Level!", 2014,http://www.bringithomepersonaltraining.com/find-the-time-toincrease-your-physical-fitness-level/. Accessed on 5 June 2017.

[6] Y. Sukarmin, \& Sudardiyono, "Physical fitness profiles of lower-level students in elementary schools based on observation guidelines," Journal of Physical Education and Sport, 2017; 17 (1), 13, 84 - 91. DOI:10.7752/jpes.2017.s1013.

[7] L. Kravitz, PanduanLengkap: Bugar Total translated from the original book Anybodys Total Fitness by Sadoso Sumosardjuno, 2001, Jakarta: PT Raja Grafindo Persada.

[8] J. Liestiufaroh, Tingkat kesegaran jasmani siswa kelas V Sekolah Dasar Negeri 1 Gambarsari Kemangkon Purbalingga, SKRIPSI, Fakultas Ilmu Keolahragaan Universitas Negeri Yogyakarta, 2013.

[9] A. A. Sulistiono, "Kebugaran jasmani siswa pendidikan dasar dan menengah di Jawa Barat," Jurnal Pendidikan dan Kebudayaan, 2014; 20(2): 223-233.

[10] K. Komhery, "Survei tingkat kesegaran jasmani siswa sekolah dasar negeri 01, Kecamatan Kayuagung, Kabupaten Ogan Komering Ilir," Fakultas Keguruan dan Ilmu Pendidikan Universitas Bina Darma Palembang, 2016.

[11] F. D. Andriyani, \& N. R. Al Adawiyah, "Physical activity level of students grade V MI Darul Hikmah Kecamatan Purwokerto Barat KabupatenBanyumas," Proceeding The $4^{\text {th }}$ International Conference on Physical Education, Sport, and Health (ISMINA), 2017; pp 175180. ISBN 978-6026121509.

[12] J. Vanhelst, L. Beghin, E. Drumez, \& Z. Ulmer, "Physical fitness levels in French adolescents: The BOUGE program," Revue $d$ Épidémiologie et de Santé Publique, 2016, DOI: 10.1016/j.respe.2016.05.002

[13] J. Vanhelst, Fardy, S. Paul, D. Chapelot Czaplicki G. \& Z. Ulmer, "Physical fitness levels of adolescents in the Ile de France region: comparisons with European standards and relevance for future cardiovascular risk," Clinical Physiology and Functional Imaging, 2015,DOI: $10.1111 /$ cpf.12253.

[14] R. M. Telford, R. D. Telford, R. B. Cunningham, T. Cochrane, R. Davey, \& G. Waddington, "Longitudinal patterns of physical activity in children aged 8 to 12 years: the LOOK study," International Journal of Behavioral Nutrition and Physical Activity, 2013; 10(81) available at http://www.ijbnpa.org/content/10/1/81.

[15] N. Lyyra, P. H. Johansson, M. Lyyra, "Exploring in-class physical activity levels during physical education lessons in Finland," Journal of Physical Education and Sport, 2017; 17(2), 124, 815 - 820. DOI:10.7752/jpes.2017.02124

[16] Kementerian Pendidikan Nasional. Tes kesegaran jasmani Indonesia untuk anak umur 13 - 15 tahun. Jakarta: Pusat Pengembangan Kualitas Jasmani, 2010

[17] https://www.statistikian.com/2014/04/mann-whitney-u-test.html. Accessed on 5 June 2017. 